\title{
ПЕААГОГІЧНІ НАУКИ
}

DOI: https://doi.org/10.32839/2304-5809/2021-3-91-17

УДК 378.018.43:811.111

Галкін О.В., Кудлай O.I.

Національний аерокосмічний університет імені М.Є. Жуковського «Харківський авіаційний інститут»

\section{СЦЕНАРНО-КОМУНІКАТИВНЕ ДИСТАНЦІЙНЕ НАВЧАННЯ АНГЛІЙСЬКОЇ МОВИ У НЕМОВНОМУ ЗВО}

\begin{abstract}
Анотація. У даній статті розглянуто сценарно-комунікативне дистанційне навчання англійської мови у немовному ЗВО. Також розглянуто методичний принцип особистісно-рольової організації учбового процесу під час дистанщійного навчання. Викладено роль викладача при недерективній регуляції поведінки студентів у групі. Описано психотерапевтичний, психогігіенічний ефект у ході процесу навчання студентів спілкуванню. Подано приклад введення студентам «легенд» у процесі реалізації сценарно-комунікативного курсу англійської мови.
\end{abstract}

Ключові слова: рольова гра, легенда, сценарій, полілог, наскрізний сюжет, сценарно-комунікативне навчання, дистанційне навчання.

Galkin Oleksandr, Kudlai Olha National Aerospace University named after M.E. Zhukovsky "Kharkiv Aviation Institute"

\section{SCENARIO-BASED COMMUNICATIVE REMOTE TEACHING OF THE ENGLISH LANGUAGE IN A NON-LINGUISTIC UNIVERSITY}

Summary. This article discusses the scenario-based communicative remote teaching of the English language in a non-linguistic university. It also discuss-es the methodological principle of the personal-role organization of the educa-tional process during remote learning. The role of a lecturer in non-directive regulation of students' behavior in a group is stated. The psychotherapeutic, psychohygienic effect in the process of teaching students to communicate is described. An example of introducing "legends" to students in the process of implementing a scenario-based communicative English language course is given. In the person-role organization of the educational process the following functions are distinguished: motivational, teaching, educational, orienting, compensatory. It is necessary to take into account personality traits, the psychotype of the students involved into communication. The scenario-based communicative education seeks to preserve all the socio-psychological aspects of natural communication and perform all its functions in the educational process. This is the specificity of scenario-based communicative teaching of foreign languages in a non-linguistic university. It is about the personality-role principle of the organization of the educational process, namely during remote learning, because role-playing communication is perceived by students as the purpose of their speech or non-speech action. The lecturer acts as a screenwriter not only for one lesson, but also for the entire foreign language course. Each lesson is developed by the lecturer as a scenario in order to organize lifelong learning through the solution of many communicative tasks presented in communicative studies. These studies are created as natural life situations, taking into account the specific language and speech material at a certain stage of their development. The depth and breadth of the functional role of the lecturer is not just limited to writing the scenario for the lesson. It is very important to direct the lesson based on the scenario, and then put it as an educational and cognitive action. Thus the lecturer acts as a playwright, screenwriter, producing director, actor, psychologist for the formation of cognitive abilities of the individual and the team.

Keywords: role play, legend, scenario, polylogue, cross-cutting plot, scenario-based communicative education, remote learning.

Постановка проблеми у загальному вигляді. Проблема оптимізації навчального процесу у різних типах навчальних закладів усе більше привертає увагу як вітчизняних, так i зарубіжних дослідників, що зумовлено пошуком інноваційних підходів до організації процесів педагогічної взаємодії. Дистанційна фрорма навчання дає сьогодні можливість створення систем масового безперервного самонавчання, загального обміну інформацією, незалежно від тимчасових і просторових поясів. Орієнтація вузівського курсу на фрормування у студентів немовних спеціальностей умінь різних видів професійного спілкування 3 використанням іноземної мови вимагає вирішення цілого ряду питань, які стосуються оптимальної організації процесу навчання згідно з сучасними вимогами та реальними вимогами викладання.

Аналіз останніх досліджень і публікацій. Питанням визначення місця та сфрер застосування технології дистанційної освіти в навчальнопізнавальному процесі, незважаючи на певну новизну проблеми, вже приділено достатньо уваги в наукових і методичних джерелах (Андрєев А.А., Кухаренко В.М., Околесов О.П., Полат Е.С., Петров А.Є., Підкасистий П.I., Моісєева М.В., Рибалко О.В., Молодих Г.С., Корнєев В.П., Твердохлєбова Н.Є., Аванесов В.С., Назаренко Т.Г., Топузов O.M., Пометун O.I., Дмітрієва В.Г., Биков В.Ю., Сиротенко Н.Г., Мокрогуз О.П., Богач- 
ков Ю.М., Александров Г.М., Машбиць Є.І., Савельев А.Я., Слівіна Н.А., Соловйов А.В. та ін.).

Виділення невирішених раніше частин загальної проблеми. Не дивлячись на велику кількість досліджень у галузі проблем формування іншомовної комунікативної компетентності студентів немовних спеціальностей, розгляд сценарно-комунікативного дистанційного навчання англійської мови у немовному 3 ВО не виявлено.

Метою статті $є$ розгляд сценарно-комунікативного дистанційного навчання англійської мови у немовному ЗВО, зокрема в національному аерокосмічному університеті імені М.Є. Жуковського "Харківський авіащійний інститут».

Виклад основного матеріалу дослідження. У світлі цих подій останнім часом як за кордоном, так і в Україні все більше уваги приділяеться проблемі викладання іноземних мов 3 урахуванням потреб майбутніх фрахівців. Доцільна і методично виправдана, таким чином, профресійна, комунікативно-направлена підготовка з іноземної мови у вищому навчальному закладі [1, с. 99].

Коли ми кажемо, що навчаємо діяльності спілкування засобом організації якого є комунікативна фрункція мови, ми припускаємо, що чим більше розвинута комунікативна фрункція у студента, тим очевидніше можливість реалізації усіх аспектів комунікативної мовленневої діяльності [4, с. 47].

Сценарно-комунікативне навчання іноземних мов у немовному ЗВО побудовано за принципом використання рольової гри. У процесі рольової гри студенти не просто імітують діяльність на базі отриманих на першому занятті «легендмасок» та оперують певною сумою знань, але виходять 3 мотиву творчої діяльності, роблять мотивовані мовленневі вчинки, розглядають рольову гру як модель міжособистісного спілкування. У цьому випадку спілкування перетворюеться на творчий особистісно-мотивований процес. У студентів виникає не тільки щирий інтерес до участі у спілкуванні, а й велика потреба в ньому. Студенти перестають бути простими статистами на занятті та перетворюються у творчих особистостей, а саме в акторів, але тільки в учбовому процесі, кожний зі своєю роллю-легендою з самого початку та на весь період сценарно-комунікативного курсу навчання.

Вищезазначене відповідає мотиващійно-спонукальній фрункції міжособистісного спілкування. Дуже важливо відзначити, що рольова гра являє собою вправу, яка виконує навчаючу функцію. Це допомагае студентам здобувати нові знання, удосконалюватися в мовній компетенції. На кож-ному занятті у студентів виховуеться свідома дисципліна, взаємодопомога, працьовитість, активність, креативність і т.д., що свідчить про те, що на кожному занятті викладач виконує виховну фрункцію. У процесі реалізації сценарнокомунікативного навчання як творчої діяльності студенти орієнтуються на планування власної мовної поведінки, розвивають вміння контролювати свої вчинки та оцінювати вчинки інших. Орієнтуюча фрункція виділяеться на даному етапі учбового процесу. Рольова гра дає можливість вийти за рамки свого контексту діяльності та дозволяе розширити його, що каже про компенсаційну фрункцію.
Таким чином, в особистісно-рольовій організації учбового процесу виділяються наступні фрункції: мотиваційно-спонукальна, навчаюча, виховна, орієнтуюча, компенсаційна.

Важливо зазначити, що навчати іноземного спілкування можна лише у безперервному процесі. Усі студенти є постійно активними суб'єктами спілкування. Вони не обмежуються простим сприйняттям повідомлення та реакцією на нього, а прагнуть виразити своє ставлення до висловлювання у відповідності до своєї ролі, тобто завжди прагнуть проявляти свої особистісні характеристики. Отже, необхідно враховувати властивості особистості, психотип студентів, які беруть участь у спілкуванні. Можна зробити висновок, що сценарно-комунікативне навчання прагне зберегти в учбовому процесі усі соціально-психологічні аспекти природного спілкування та здійснити усі його фрункщії. У цьому полягає специфріка сценарно-комунікативного навчання іноземних мов у немовному ЗВО. Зрозуміло, що мова йде про особистісно-рольовий принцип організації учбового процесу, а саме під час дистанційного навчання, оскільки рольове спілкування сприймається студентами в якості мети їхньої мовленнєвої чи немовленнєвої дії. Умови комунікативного навчання у високому ступені наближаються для студента до неучбової спільної діяльності.

Відсутність у відносинах учнів та вчителя статусу мовленнєвих партнерів виникає як раз з відсутності комунікативної мотивації (обох видів). Комунікативний метод покликаний у корні змінити це положення [5, с. 17].

Що стосуеться викладача, то його фрункція у сценарно-комунікативному навчанні значно глибше та ширше, ніж фрункція студента. Викладач виступає як сценарист не тільки одного заняття, а й усього курсу навчання іноземної мови. Кожне заняття розробляється викладачем як сценарій 3 метою організації безперервного навчання через розв'язання безлічі комунікативних задач, пред'явлених у комунікативних етюдах. Ці етюди створюються як природні життеві ситуації з урахуванням конкретного мовного та мовленневого матеріалу на певному етапі їхнього відпрацювання. Глибина та ширина фрункціональної ролі викладача не обмежуеться тільки лише написанням сценарію заняття. Дуже важливо поставити режисуру заняття, базуючись на сценарії, а потім поставити його як учбово-пізнавальне дійство. Для викладачів це дійство $е$ крім того учбовим, оскільки воно плануеться, організовуеться та управляеться ними для цілей формування, відпрацювання та закріплення навичок та вмінь усіх видів мовленневої діяльності. Виходячи 3 цього положення можна зробити висновок, що рольова гра - це одночасно і ігрова, і учбова, і мовленнева діяльність. Отже, реалізуючи вищезазначене, викладач виступає в учбовому процесі як режисер-постановник свого заняття-сценарію. На цьому процесі творчі здібності викладача не закінчуються, а отримують свій стрімкий розвиток. Викладач разом зі студентами-акторами виступає як актор свого ж заняття-дійства, а саме: учбового спектаклю.

Знімаючи психологічні бар'ери у студентів, викладач закликає їх не соромитися висловлювати- 
ся іноземною мовою, не боятися робити помилки, відкриває та активізуе творчі здібності студентів як особистостей та колективу в цілому. Тільки психолог може створити на занятті та у всьому курсі сценарно-комунікативного навчання іноземних мов атмосфреру доброзичливості, великодушності, підтримки, схвалення, заохочення, взаємодопомоги та співпереживання. Таким є психологічне емоційне забарвлення мовленнєвої поведінки кожного в ситуаціях учбових текстів, а в результаті - позитивний настрій, підвищений емоційний тонус усього начального процесу. Підсумовуючи роль та фрункцію викладача у сценарно-комунікативному навчанні іноземної мови у немовному ЗВО, можна зробити висновок, що в сценарно-комунікативному навчанні викладач виступає як драматург, сценарист, режисер-постановник, актор, психолог по формуванню пізнавальних здібностей особистості та колективу.

Природні життеві ситуащії учасників безперервного спілкування можуть реалізовуватися через полілог, який становиться основним учбо-вим текстом. Полілог, мовленнева діяльність усіх учасників спілкування, є тематичним та вводиться на самому початку кожного розділу. Відповідно до сюжетної стратегії курсу навчання кожен студент отримуе свою "легенду». "Легенда» вручаеться студенту на самому початку навчання на першому занятті.

Слід відзначити, що зміна імен - одна з найважливіших психологічних та педагогічних умов, які сприяють едективному управлінню спілкуванням. 3 психологічної точки зору кожна роль дозволяє студенту перевтілитися у нову особу, яка вступає в нові соціальні відносини. Зміняться відносини з усіма членами групи, які також отримали свої нові ролі. Фактично це і $є$ один 3 прийомів методу недерективної регуляції поведінки студентів у групі.

Нижче приведений приклад введення студентам «легенд» у процесі реалізації сценарно-комунікативного курсу англійської мови.

\section{Scenario}

The International Forum is being held in Kharkov. The topic of the Forum is "Our Home is the Earth". The Forum attracts attention of good will people all over the world. Peace ambassadors have arrived in Kharkov to take an active part in elaboration of mutual European Home project. Some outstanding scientists, state and public figures, famous poets, writers, actors, businessmen are present at the Forum.

One of the most brilliant Forum participants is Alexander Golding, a famous psychologist from the United Kingdom. He has a mission to organize a team of talented and extraordinary Forum participants and invite them to Cambridge University. They are supposed to participate at the press conference, to share their impressions about the Forum, to deliver lectures for the students of Cambridge University, to take part at TV talk shows.

Alexander Golding has made his choice and now you are having a pleasure of meeting these noble and decent people.

A famous Spanish theatre and cinema actress Jessica Topano was the first to receive the invitation. She is going to take an active part in the Press conference at Cambridge University and tell the students of Cambridge and the guests of the Press conference about her creative life. Jessica is also looking forward to sharing her impressions about the Forum.

The other participants of our Forum are Donna Castro, a journalist from Italy, and Yoko Yango, a University student from Japan. Donna and Yoko are adornment of the group. Donna likes to ask questions "What?", "When?", "Where?". She was invited to take part in the team of European intellect stars in the TV game "What? Where? When?".

Both girls are not married. Several ИТАРTACC correspondents in Moscow proposed them to get married, but the girls resolutely rejected their proposals.

A very important participant of the group is Maurice Morgan. He is a lawyer by his profession. Maurice is the only non-European member of the group. Maurice comes from Canada. He successfully works in the field of market economy legislation. Particularly, he helped Ukrainian government in elaboration of the project for transition on market relations. At present he is leaving for the UK on the invitation of Cambridge University. Maurice Morgan will make a report for the students and deliver several lectures.

Monica Childs is departing to the United Kingdom too. She works for a model agency as a deputy director. This businesswoman has arrived in our country to establish business relations with Ukrainian partners on the basis of mutual benefit. Mrs. Childs is determined that Ukraine is abundant in charming and beautiful girls, so she looks forward to sharing with Ukrainian model agencies her experience of grooming models, putting them on the road to success.

Another important representative of our international group is Marta Dundy. Marta is a University lecturer from Sweden. She has got married re-cently. Lecturers in Sweden are paid high salaries, that's why the Dundies' married couple dreams of having five children, taking into account the fact that their future is brilliant.

Another happy family woman is Michelle Muriel. Michelle comes from France. She has got married recently. It was a Church Wedding and a day to remember all their life. Young lady's ambition is to make career in sociology.

Both ladies kindly accept the invitation and now they are busy preparing their reports and lectures for the students of Cambridge University.

Anna Grossberg is also departing to the United Kingdom. Anna is a bank manager from Switzerland. She was working as an international Monetary Fund expert in Kiev helping Ukrainian partners to lay down stable and cooperative monetary system. Anna Grossberg's mission proved to be useful and effective and now she is eager to share her professional knowledge with young generation.

The last but a very important participant of our international group is a poet from Ireland Sandy Bard. Sandy is one of the brightest persons in our group. His poetry is known and popular in his motherland.

Everything goes perfectly well. Business class airplane tickets are reserved, comfortable rooms 
in the first class hotel with delicious cookery are booked, cultural and sport programs are agreed. Only one thing is left: to learn communicating good English. It is so important to do this in order to pass successfully through Immigration Control, to fill in the Customs declaration correctly, to write business letter to your business partner or a resume to your employer without mistakes. It is also important for you to communicate good English in order to ask a passerby for direction, to get information from directory inquiries, to check in or out of a hotel, to make airplane or hotel reservations, to have a long distance call, to keep your head at a supermarket buying cloths or foodstuff or to be able to buy concert, performance, tickets etc.

But before doing these things the group would like to get acquainted with each other closer because remarkable people have gathered together.

\begin{tabular}{|l|l|}
\hline 1. Jessica Topano & 6. Marta Dundy \\
\hline Theatre and cinema actress & University lecturer \\
\hline Spaniard & Swede \\
\hline Spain & Sweden \\
\hline 2. Donna Castro & 7. Michelle Muriel \\
\hline Journalist & Sociologist \\
\hline Italian & French \\
\hline Italy & France \\
\hline 3. Yoko Yango & 8. Anna Grossberg \\
\hline University student & Bank manager \\
\hline Japanese & Swiss \\
\hline Japan & Switzerland \\
\hline 4. Maurice Morgan & 9. Sandy Bard \\
\hline Lawyer & Poet \\
\hline Canadian & Irish \\
\hline Canada & Ireland \\
\hline 5. Monica Childs & 10. Alexander Golding \\
\hline Deputy director & Psychologist \\
\hline Dutch & English \\
\hline Holland & The United Kingdom \\
\hline
\end{tabular}

\section{Список літератури:}

1. Галкін О.В. Використання двосторонньої дистанційної взаемодії в начанні іноземних мов в немовних ВНЗ (Viber, Skype, Web-conferences). Молодий вчений. 2020. № 2(78). C. 98-103.

2. Гальскова Н.Д., Гез Н.И. Теория обучения иностранным языкам. Лингводидактика и методика. Москва : Академия, 2006. $336 \mathrm{c.}$

3. Зимняя И.А. Лингвопсихология речевой деятельности. Москва : Московский психолого-социальный институт. Воронеж : НПО "МОДЭК", 2001. 432 с.

4. Китайгородская Г.А. Методические основы интенсивного обучения иностранным языкам. Москва : Издательство Московского университета, 1986. $175 \mathrm{c.}$

5. Пассов Е.И. Коммуникативный метод обучения иностранному говорению. Москва : Просвещение, 1991. 223 с.

6. Пассов Е.И. Основы коммуникативной методики обучения иноязычному общению. Москва : Русский язык, 1989. $276 \mathrm{c}$.

7. Brumfit Ch. \& Johnson K. The communicative approach to Language teaching. Oxford University Press, 1979.

8. Hatch E. Discourse and Language Education. Cambridge University Press, 1994.

9. Hymes D. Models of the interaction and social life. In J. Gumperz \& D. Hymes (Eds.), Directions in Sociolinguistics: The Ethnography of Communication. New York: Holt, Rine-hart, Winston, 1972.

10. Littlewood W. Communicative Language Teaching. Cambridge University Press, 1981.

11. Schank R., Abelson R. Scripts, plans, goals, and understanding. Hillsdale, N.J: Lawrence Erlbaum Associates, 1977.

\section{References:}

1. Galkin O.V. (2020) Vykorystannia dvostoronnoi dystantsiinoi vzaiemodii v nachanni inozemnykh mov v nemovnykh VNZ (Viber, Skype, Web-conferences) [Use of two-way remote interaction in teaching foreign languages in nonlinguistic universities (Viber, Skype, Web-conferences)]/ Molodyi vchenyi, vol. 2(78), pp. 98-103.

2. Galskova N.D., Gez N.I. (2006) Teoriya obucheniya inostrannym yazykam. Lingvodidaktika i metodika [The theory of teaching foreign languages. Linguodidactics and methodoly]/ Moskva: Akademiya, $336 \mathrm{p}$. 
3. Zimnyaya I.Y. (2001) Lingvopsixologiya rechevoj deyatelnosti [Linguopsychology of speech activity]. Voronezh: NPO "MODEK", 432 p.

4. Kitajgorodskaya G.A. (1986) Metodicheskie osnovyintensivnogo obucheniya inostrannym yazykam [Methodological foundations of the intensive teaching of foreign languages]. Moskva: Izdatelstvo Moskovskogo universiteta, $175 \mathrm{p}$.

5. Passov E.I. (1991) Kommunikativnyj metod obucheniya inostrannomu govoreniyu [The communicative method of teaching foreign speaking]/ Moskva: Prosveshhenie, $223 \mathrm{p}$.

6. Passov E.I. (1989) Osnovy kommunikativnoj metodiki obucheniya inoyazychnomu obshheniyu [Fundamentals of communicative methods of teaching foreign language communication]. Moskva: Russkij yazyk, $276 \mathrm{p}$.

7. Brumfit Ch., Johnson K. (1979) The communicative approach to Language teaching. Oxford University Press.

8. Hatch E. (1994) Discourse and Language Education. Cambridge University Press.

9. Hymes D. (1972) Models of the interaction and social life. In J. Gumperz \& D. Hymes (Eds.), Directions in Sociolinguistics: The Ethnography of Communication. New York: Holt, Rinehart, Winston.

10. Littlewood W. (1981) Communicative Language Teaching. Cambridge University Press.

11. Schank R., Abelson R. (1977) Scripts, plans, goals, and understanding. Hillsdale, N.J: Lawrence Erlbaum Associates. 